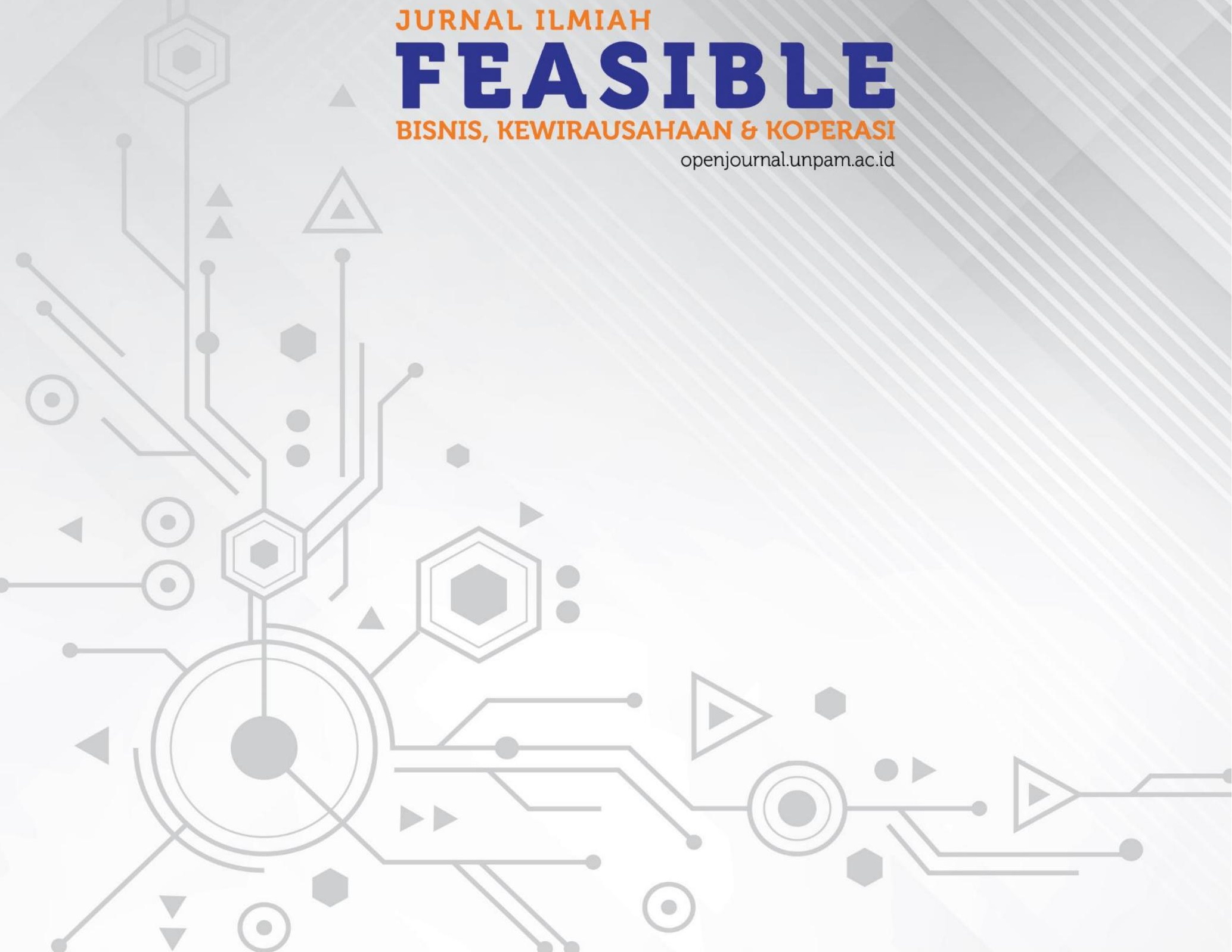




\title{
PENGARUH CURRENT RATIO DAN NET PROFIT MARGIN TERHADAP HARGA SAHAM PADA PERUSAHAAN MAKANAN DAN MINUMAN YANG TERDAFTAR DI BURSA EFEK INDONESIA (BEI) PERIODE 2015-2018
}

\author{
Iriana Kusuma Dewi') ; Dede Solihin²) \\ Fakultas Ekonomi, Universitas Pamulang \\ dosen01729@unpam.ac.id
}

\begin{abstract}
Abstrak
Tujuan diadakannya penelitian ini adalah untuk mengetahui dan menganalisis pengaruh Current Ratio dan Net Profit Margin terhadap harga saham pada perusahaan makanan dan minuman yang terdaftar di Bursa Efek Indonesia (BEI) periode 2015-2018. Metode yang digunakan dalam penelitian ini menggunakan metode deskriptif kuantitatif. Populasi dalam penelitian ini adalah seluruh perusahaan makanan dan minuman yang terdaftar di Bursa Efek Indonesia sebanyak 18 perusahaan. Sampel yang digunakan dalam penelitian ini sebanyak 10 perusahaan pada periode 2015-2018. Teknik pengumpulan data daam penelitian ini menggunakan data sekunder. Adapun teknik analisis data menggunakan Uji Asumsi Klasik, Regresi Linier Berganda, koefisien determinasi dan pengujian hipotesis parsial serta simultan. Hasil penelitian menunjukan bahwa:1). Secara parsial current ratio berpengaruh negatif dan signifikan terhadap harga saham. 2). Secara pasrsial net proft margin berpengaruh positif dan signifikan terhadap harga saham. 3). Secara simultan current ratio dan net profit margin berpengaruh positif dan signifikan terhadap harga saham.
\end{abstract}

Kata Kunci : Current Ratio; Net Profit Margin; Harga Saham

\begin{abstract}
The purpose of this research is to find out and analyze the effect of Current Ratio (CR) and Net Profit Margin (NPM) on stock prices in food and beverage companies listed on the Indonesia Stock Exchange (BEI) for the 2015-2018 period. The method used in this study uses quantitative descriptive methods. The population in this study were all food and beverage companies listed on the Indonesia Stock Exchange as many as 18 companies. The samples used in this study were 10 companies in the 2015-2018 period. Data collection techniques in this study using secondary data. The data analysis technique uses the Classical Assumption Test, Multiple Linear Regression, the coefficient of determination and partial and simultaneous hypothesis testing. The results of this study indicate that: (1). Current Ratio has a negative and significant effect on stock prices. (2). Net Profit Margin has a positive and significant effect on stock prices. (3). Current Ratio and Net Profit Margin simultaneously have a positive and significant effect on stock prices.
\end{abstract}

Keywords : Current Ratio; Net Profit Margin; Stock Price 


\section{PENDAHULUAN}

Perusahaan makanan dan minuman merupakan kategori barang konsumsi perusahaan manufaktur dimana produknya sangat dibutuhkan masyarakat, sehingga prospek menguntungkan baik dimasa sekarang maupun dimasa yang akan datang, selain itu saham perusahaan tersebut merupakan saham yang paling tahan krisis ekonomi dibandingkan dengan sektor lain karena dalam kondisi krisis atau tidak sebagian besar produk makanan dan minuman tetap dibutuhkan masyarakat. Selain itu karakteristik dari masyarakat yang cenderung gemar berbelanja makanan, dapat membantu mempertahankan. Sehingga saham pada perusahaan makanan dan minuman lebih banyak menarik minat investor.

Tabel 1.1. Rata-Rata CR, NPM dan Harga Saham Periode 2015-2018

\begin{tabular}{|l|c|c|c|c|}
\hline \multirow{2}{*}{ Variabel } & \multicolumn{4}{|c|}{ Tahun } \\
\cline { 2 - 5 } & 2015 & 2016 & 2017 & 2018 \\
\hline Current Ratio & 2,31 & 2,68 & 2,69 & 2,90 \\
\hline NPM & 0,095 & 0,123 & 0,128 & 0,117 \\
\hline Harga Saham & 4092,2 & 4288,7 & 4238,4 & 4762,9 \\
\hline
\end{tabular}

Sumber: Datadiolah

Berdasarkan pada tabel tersebut dapat diketahui bahwa current ratio selama periode 2015-2018 mengalami fluktuasi dimana current ratio tertinggi terjadi pada tahun 2018 sebesar 2,90 sedangkan current ratio terendah pada tahun 2015 sebesar 2,31. NPM selama periode 2015-2018 juga mengalami fluktuasi setiap tahun dimana NPM tertinggi terjadi pada tahun 2017 sebesar 0,128 sedangkan NPM terendah pada tahun 2018 sebesar 0,117. Harga

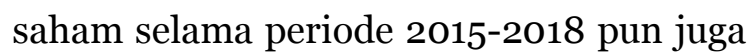
demikian mengalami fluktuasi dimana harga saham tertinggi terjadi pada tahun 2018 sebesar Rp. 4762,9 sedangkan harga saham terendah pada tahun 2015 sebesar Rp. 4092,2.

"Harga saham dapat dipengaruhi oleh faktor internal dan eksternal yaitu faktor internal seperti laba perusahaan, pertumbuhan aktiva tahunan, likuiditas, nilai kekayaan total penjualan, sedangkan faktor eksternal seperti kebijakan pemerintah dan dampaknya, pergerakan suku bunga, fluktuasi nilai tukar mata uang, rumor, sentimen pasar dan penggabungan usaha”. (Yuliana, 2010:60).

Kelancaran proses produksi suatu perusahaan di pengaruhi oleh likuiditas perusahaan, semakin tinggi tingkat rasio perusahaan maka semakin tinggi pula posisi likuiditas perusahaan. Pengukuran rasio likuiditas dapat menggunakan rasio lancar (current ratio). Menurut Fahmi (2015:121), "Rasio lancar (current ratio) adalah ukuran yang umum digunakan atau solvensi jangka pendek, kemampuan suatu perusahaan memenuhi kebutuhan utang ketika jatuh tempo".

Menurut Murhadi (2013:64) "Net Profit Margin (NPM) mencerminkan kemampuan perusahaan dalam menghasilkan laba neto dari setiap penjualannya, semakin tinggi nilai NPM maka menunjukkan semakin baik, laba yang tinggi akan menarik investor untuk 
menanamkan modalnya yang menyebabkan harga saham meningkat”.

Penelitian yang dilakukan oleh Manopo, Tewal dan Arrazi (2017), hasil penelitian menunjukan CR, DER, ROA dan NPM secara simultan berpengaruh signifikan terhadap Harga Saham. Juga diperkuat oleh penelitian Arifin, Silviana dan Agustami (2016), yang meneliti pada perusahaan Subsektor Perkebunan Yang Terdaftar Di Bursa Efek Indonesia Tahun 2010-2014 hasil penelitian menunjukan bahwa secara bersamaan likuiditas, solvabilitas, profitabilitas, rasio pasar, dan ukuran perusahaan memberikan pengaruh yang signifikan terhadap harga saham.

Berdasarkan uraian di atas, maka penulis tertarik untuk melakukan penelitian dengan judul: "Pengaruh Current Ratio dan Net Profit Margin Terhadap Harga Saham Pada Perusahaan Makanan dan Minuman Yang Terdaftar di Bursa Efek Indonesia (BEI) Periode 20152018”.

Sesuai dengan latar belakang di atas, maka penulis merumuskan masalah sebagai berikut:

1. Bagaimana pengaruh Current Ratio terhadap harga saham pada perusahaan makanan dan minuman yang terdaftar di Bursa Efek Indonesia (BEI) periode 2015-2018?

2. Bagaimana pengaruh Net Profit Margin terhadap harga saham pada perusahaan makanan dan minuman yang terdaftar di Bursa Efek Indonesia (BEI) periode 2015-2018?
3. Bagaimana pengaruh Current Ratio dan Net Profit Margin secara simultan terhadap harga saham pada perusahaan makanan dan minuman yang terdaftar di Bursa Efek Indonesia (BEI) periode 2015-2018?

\section{METODE}

Penelitian ini menggunakan metode penelitian deskriptif kuantitatif. Menurut Sugiyono (2017:35), "Metode deskriptif adalah penelitian yang dilakukan untuk mengetahui keberadaan variabel mandiri, baik hanya pada satu variabel atau lebih (variabel yang berdiri sendiri) tanpa membuat perbandingan dan mencari hubungan variabel itu dengan variabel yang lain, sedangkan data kuantatif adalah data penelitian berupa angka-angka, yang akan dianalisis menggunakan data statistik dan bertujuan untuk menguji hipotesis yang telah ditetapkan". Populasi dalam penelitian ini adalah seluruh perusahaan sektor manufaktur subsektor makanan dan minuman yang terdaftar di Bursa Efek Indonesia periode 2015-2018. Teknik sampling dengan purposive sampling. Sampel dalam penelitian ini berjumlah 10 perusahaan. Sementara itu teknik analisis data menggunakan, Statistik Deskriptif, Uji Asumsi Klasik, Regresi Linier Berganda dan pengujian hipotesis.

\section{HASIL dan PEMBAHASAN}

\section{Harga Saham}

Darmadji dan Fakhrudin (2012:102), "Harga yang terjadi di bursa pada waktu 
tertentu, harga saham bisa berubah naik atau pun turun dalam hitungan waktu yang begitu cepat, ia dapat berubah dalam hitungan menit bahkan dapat berubah dalam hitungan detik, hal tersebut dimungkinkan karena tergantung dengan permintaan dan penawaran antara pembeli saham dengan penjual saham”. Menurut Widoatmodjo (2012:45), "Harga saham merupakan harga atau nilai uang yang bersedia dikeluarkan untuk memperoleh atas suatu saham”. Sartono (2008:70) menyatakan bahwa: "Harga saham terbentuk melalui mekanisme permintaan dan penawaran di pasar modal, apabila suatu saham mengalami kelebihan permintaan, maka harga saham cenderung naik, sebaliknya, apabila kelebihan penawaran maka harga saham cenderung turun”.

\section{Current Ratio}

Menurut Fahmi (2015:121), "Rasio lancar adalah ukuran yang umum digunakan atau solvensi jangka pendek, kemampuan suatu perusahaan memenuhi kebutuhan utang ketika jatuh tempo". Kasmir (2016:134) menyatakan bahwa "Rasio lancar merupakan rasio untuk mengukur kemampuan perusahaan membayar kewajiban jangka pendek atau utang yang segera jatuh tempo pada saat ditagih secara keseluruhan".

\section{Net Profit Margin}

Menurut Kasmir (2016:200) "NPM merupakan rasio yang digunakan untuk mengukur margin laba atas penjualan, rasio ini akan menggambarkan penghasilan bersih perusahaan berdasarkan total penjualan”. Menurut Syamsuddin (2014:62) "Net profit margin adalah merupakan rasio antara laba bersih (Net Profit) yaitu penjualan sesudah dikurangi dengan seluruh expense termasuk pajak dibandingkan dengan penjualan, semakin tinggi NPM, semakin baik operasi suatu perusahaan".

\section{Hasil}

Statistik Deskriptif

Tabel 1.2. Statistik Deskriptif

\begin{tabular}{|l|r|r|r|r|r|}
\hline & \multicolumn{1}{|c|}{$\mathrm{N}$} & Ninimum & Maximum & \multicolumn{1}{c|}{ Mean } & Std. Deriation \\
\hline Current Ratio & 40 &, 580 & 8,640 & 2,64550 & 1,9948900 \\
\hline Net Profit Nargin & 40 & -047 &, 390 &, 11575 &, 116481 \\
\hline Harrga Saham & 40 & 122 & 15992 & 4345,55 & 4341,395 \\
\hline Validd N(listivise) & 40 & & & & \\
\hline
\end{tabular}

Output pada tabel di atas menunjukkan jumlah data yang diteliti berjumlah 40 data. CR menghasilkan nilai maximum 8,640 dan nilai minimum sebesar 0,580 , mean variabel $\mathrm{CR}$ 2,64550, standar deviasi sebesar 1,994890. NPM menghasilkan nilai maximum 0,390, nilai minimum -0,047, mean CR 0,11575 dengan std deviation o,116481. Sedangkan hasil uji statistik deskriptif Harga Saham menghasilkan nilai maximum 15992, nilai minimum 122. Nilai mean, 4345,55 dengan std deviation 4341,395 .

\section{Uji Asumsi Klasik}

\section{Uji Normalitas}




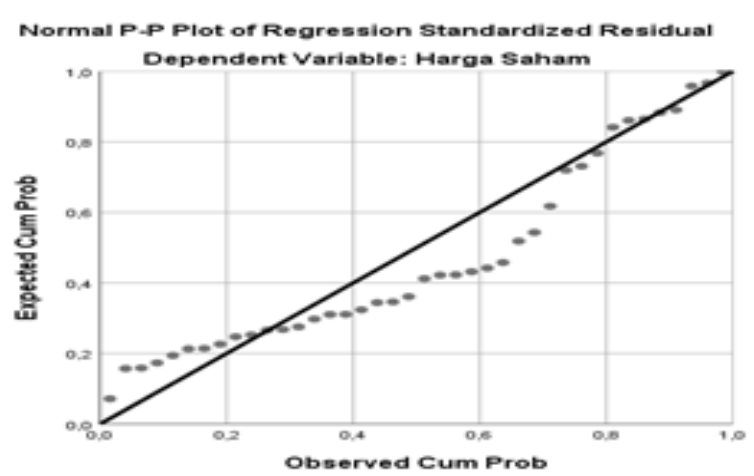

Gambar 1.1. Hasil Uji Normalitas

Untuk grafik Normal P-Plot pada gambar di atas juga terlihat bahwa titik-titik itu mengikuti garis diagonal meskipun sedikit menyebar tetapi penyebarannya tidak terlalu jauh dari garis diagonalnya. Hal ini menunjukkan bahwa grafik menunjukkan pola distribusi normal. Maka model regresi memenuhi asumsi normalitas.

\section{Uji Multikolineritas}

Uji Heteroskedastisitas bertujuan untuk menguji apakah dalam model regresi terjadi ketidaksamaan varian dari residual satu pengamatan ke pengamatan yang lain. (Ghozali, 2016).

\begin{tabular}{l}
\hline \multicolumn{2}{|c|}{ Tabel 1.3. Uji Multikolinieritas } \\
\begin{tabular}{|c|l|c|c|}
\hline \multirow{2}{*}{\multicolumn{2}{|c|}{ Model }} & \multicolumn{2}{c|}{ Collinearity Statistics } \\
\cline { 3 - 4 } & Tolerance & VIF \\
\hline 1 & (Constant) & & \\
\hline & Curnent Ratio & 0,747 & 1,338 \\
\hline & Net Profit Magin & 0,747 & 1,338 \\
\hline
\end{tabular} \\
a. Dependent Variable: Harga Saham \\
\end{tabular}

Tabel di atas menunjukkan bahwa hubungan antar kedua variabel bebas menunjukan nilai tolerance tidak menunjukan multikolinearitas, karena nilai tolerance $\mathrm{CR}$ dan $\mathrm{NPM}>$ dari 0,10. Demikian juga dari nilai VIF menunjukan tidak terdapat multikolinearitas, karena nilai VIF CR dan NPM $<10$.

\section{Uji Heteroskedastisitas}

Tabel 1.4. Uji Heteroskedastisitas

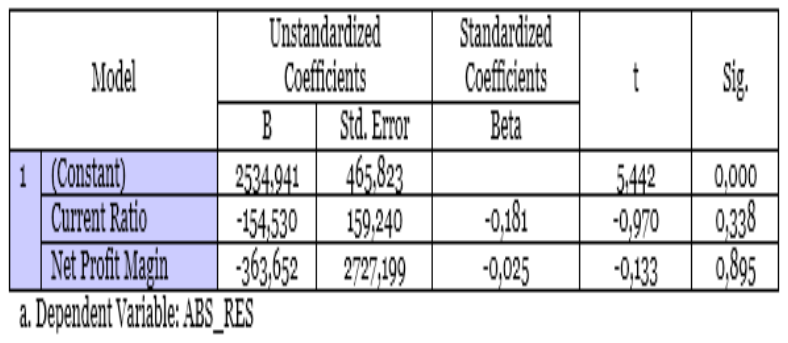

Dari output yang dijelaskan di atas, tampak jelas bahwa kedua variabel tidak menunjukkan heteroskedastisitas hal ini dilihat dari nilai Sig. > 0,05.

\section{Uji Autokorelasi}

Tabel 1.5. Uji Durbin Watson

\begin{tabular}{|c|c|c|c|c|c|}
\hline Nodel & $R$ & RSquare & Adjusted R Square & $\begin{array}{c}\text { Std. Error of the } \\
\text { Estimate }\end{array}$ & Durbin-Watson \\
\hline 1 &, $8399^{-1}$ & 0,704 & 0,678 & 2480,878 & 1,916 \\
\hline
\end{tabular}

a. Predictors: (Constant), LAG_Y, Current Ratio, Net Profit Nargin

b. Dependent Variable: Harga Saham

Berdasarkan tabel tersebut diketahui bahwa nilai durbin watson sebesar 1,916 yang artinya $1,600<1,916<2,400$. Pembanding menggunakan nilai signifikansi 5\%, jumlah sampel 40 (n), dan jumlah variabel independen $2(\mathrm{k}=2)$, maka di tabel Durbin Watson akan didapat nilai du sebesar 1,600. Karena nilai DW 1,916 lebih besar dari batas atas (du) 1,600 dan kurang dari 4 - $(1,600)=2,400$, maka dapat disimpulkan bahwa tidak terdapat autokorelasi pada data yang digunakan pada penelitian ini.

\section{Regresi Linier Berganda}

Tabel 1.6. egresi Linier Berganda 


\begin{tabular}{|c|c|c|c|c|c|c|}
\hline \multirow{2}{*}{\multicolumn{2}{|c|}{ Model }} & \multicolumn{2}{|c|}{ Unstandardized Coefficients } & Standardized & \multirow{2}{*}{$t$} & \multirow{2}{*}{ Sig, } \\
\hline & & $B$ & Std. Error & Beta & & \\
\hline \multirow[t]{3}{*}{1} & (Constant) & 3699,106 & 756,245 & & 4,891 & 0,000 \\
\hline & Current Ratio & $-1214,293$ & 258,520 & $-0,558$ & $-4,697$ & 0,000 \\
\hline & Net Profit Nagain & 33337,859 & 4427,493 & 0,894 & 7,530 & 0,000 \\
\hline
\end{tabular}

$Y=3699,106-1214,293 X_{1}+$

\section{$\mathbf{3 3 3 3 7}, \mathbf{8 5 9} \mathrm{X}_{\mathbf{2}}$}

1. Konstanta sebesar 3699,106 , hal ini menunjukkan bahwa apabila semua variabel independent (Current Ratio dan Net Profit Margin) bernilai o, maka harga saham akan tetap Rp. 3699,106.

2. Variabel Current Ratio $\left(\mathrm{X}_{1}\right)$ mempunyai koefisien regresi bernilai negatif sebesar -1214,293, Hal ini menunjukkan bahwa setiap penambahan satu kali Current Ratio maka akan menurunkan harga saham sebesar Rp -1214,293 dengan asumsi variabel Net Profit Margin tetap.

3. Variabel Net Profit Margin $\left(\mathrm{X}_{2}\right)$ mempunyai koefisien regresi bernilai positif sebesar 33337,859 , Hal ini menunjukkan bahwa setiap penambahan satu kali Net Profit Margin maka akan meningkatkan harga saham sebesar Rp 33337,859 dengan asumsi variabel Current Ratio tetap.

\section{Uji t}

Berdasarkan hasil pengujian pada tabel 1.6, Variabel CR memiliki angka sig 0,00o < 1\% (o,01) sehingga CR $\left(\mathrm{X}_{1}\right)$ mempengaruhi harga saham (Y) dan signifikan. Variabel NPM yang ditunjukkan pada Tabel 1.6 memiliki angka Sigg 0,00o < 1\% (0,01) sehingga NPM $\left(\mathrm{X}_{2}\right)$ mempengaruhi Harga Saham (Y) secara signifikan.

\section{Uji F}

\begin{tabular}{l}
\hline \multicolumn{7}{c}{ Tabel 1.7. Uji F Simultan } \\
\begin{tabular}{|c|c|c|c|c|c|c|}
\hline \multicolumn{2}{|c|}{ Nodel } & Sum of Squares & df & Mean Square & F & Sig. \\
\hline \multirow{2}{*}{1} & Regression & 448206302,281 & 2 & 224103151,440 & 28,906 &, $000^{\circ}$ \\
\cline { 2 - 7 } & Residual & 286854329,619 & 37 & 7752819,719 & & \\
\cline { 2 - 7 } & Total & 735060631,900 & 39 & & & \\
\hline
\end{tabular} \\
a. Dependent Variable: Harga Saham \\
b. Predictors: (Constant), Profitabilitas, Likuiditas
\end{tabular}

Hasil pada tabel 1.7 diperoleh angka $0,018<1 \%$, membuktikan bahwa secara bersamaan CR dan NPM mempengaruhi Harga Saham secara signifikan.

\section{Koefisen Determinasi}

Tabel 1.8. Uji Koefisien Determinasi

\begin{tabular}{|c|c|c|c|c|c|}
\hline Model & $R$ & RSquare & Adiusted R Square & $\begin{array}{c}\text { Std. Emror of the } \\
\text { Estimate }\end{array}$ & Durbin-Watson \\
\hline 1 &, $839^{9}$ & 0,704 & 0,678 & 2480,878 & 1,916 \\
\hline
\end{tabular}
b. Dependent Variable: Harga Saham

Berdasarkan tabel 1.8, CR $\left(\mathrm{X}_{1}\right)$ dan NPM $\left(X_{2}\right)$ selama periode 2015-2018 memberikan kontribusi sebesar 70,4\% terhadap Harga Saham (Y), adapun kontribusi yang disebabkan oleh variabel lain sebesar 29,6\%.

\section{Pembahasan}

\section{Pengaruh CR Terhadap Harga Saham}

Variabel current ratio berpengaruh negatif dan signifikan terhadap harga saham hal ini dapat dibuktikan dari nilai regresi bernilai negatif sebesar -1214,293, Hal ini menunjukkan bahwa setiap penambahan satu kali likuiditas maka akan menurunkan harga saham sebesar Rp 1214,293 serta nilai $t_{\text {hitung }}$ sebesar -4,697< $t_{\text {tabel }}$ 2,024 dengan nilai signifikan sebesar $0,000<0,05$.

Hasil penelitian ini didukung oleh penelitian sebelumnya yang dilakukan oleh 
Wiwi Restiana (2016) dengan judul Pengaruh Current Ratio (CR), Debt to Equity Ratio (DER), dan Return On Equity (ROE) Terhadap Harga Saham Perusahan Subsektor perkebunan yang terdaftar di Bursa Efek Indonesia Tahun 2012-2015 hasi penelitian menunjukan bahwa Current Ratio secara parsial berpengaruh negatif dan signifikan terhadap harga saham. Juga didukung oleh penelitian Elwisam (2018), dengan judul Pengaruh Current Ratio, Return On Asset, Debt to Equity Ratio, dan Total Assets Turnover Terhadap Harga Saham Pada Perusahaan LQ45 Tahun 20132015. Menyatakan bahwa current ratio berpengaruh negatif dan signifikan terhadap harga saham.

\section{Pengaruh NPM Terhadap Harg Saham}

Variabel Net Profit Margin (NPM) berpengaruh positif dan signifikan terhadap harga saham hal ini dapat dibuktikan dari nilai Regresi yang bernilai positif sebesar 33337,859 , Hal ini menunjukkan bahwa setiap penambahan satu kali profitabilitas maka akan meningkatkan harga saham sebesar Rp 33337,859 serta nilai thitung 7,530 $>t_{\text {tabel }}$ 2,024 dengan nilai signifikan sebesar $0,000<0,05$.

Hasil penelitian ini dikung oleh penelitian Tirza dan Syamsuri (2015), Hasil penelitian menunjukan bahwa terdapat pengaruh positif dan signifikan antara variabel profitabilitas terhadap harga saham. Penelitian Manopo, Tewal dan Arrazi (2017), hasil penelitian menunjukan
ROA dan NPM berpengaruh signifikan terhadap Harga Saham.

\section{Pengaruh CR dan NPM Terhadap Harga Saham}

Variabel Current Ratio (CR) dan Net Profit Margin (NPM) secara simultan berpengaruh positif dan signifikan terhadap harga saham hal ini dapat dibuktikan dari nilai $F_{\text {hitung }} 28,906>F_{\text {tabel }}$ 4,11 dengan siginifikan $0,000<0,05$. Adapun variabel Current Ratio (CR) dan Net Profit Margin (NPM) secara simultan memberikan pengaruh/kontribusi terhadap harga saham sebesar 61\% sedangkan sisanya yaitu 39\% merupakan faktor lain yang tidak diteliti oleh penulis.

Hasil penelitian ini dikung oleh penelitian Amanah, Atmanto dan Azizah (2014), yang meneliti pada Perusahaan Indeks LQ45 Periode 2008-2012. Hasil penelitian menunjukan bahwa bahwa secara simultan variabel likuiditas dan profitabilitas berpengaruh signifikan terhadap variabel harga saham. Penelitian yang dilakukan oleh Octaviani dan Komalasari (2017), yang meneliti sembilan Perusahaan Perbankan yang Terdaftar di Bursa Efek Indonesia periode 2011-2015, hasil penelitian menunjukan bahwa Current Ratio, Return on Asset and Debt to Equity Ratio secara simultan berpengaruh signifikan terhadap harga saham. Juga diperkuat oleh penelitian Arifin, Silviana dan Agustami (2016), yang meneliti pada perusahaan Subsektor Perkebunan Yang Terdaftar Di Bursa Efek Indonesia Tahun 2010-2014 hasil penelitian menunjukan 
bahwa secara bersamaan likuiditas, solvabilitas, profitabilitas, rasio pasar, dan ukuran perusahaan memberikan pengaruh yang signifikan terhadap harga saham.

\section{SIMPULAN}

Berdasarkan hasil penelitian dan pembahasan yang sudah dilakukan, dapat disimpulkan bahwa, Secara parsial current ratio berpengaruh negatif dan signifikan terhadap harga saham artinya setiap penambahan satu kali current ratio maka akan menurunkan harga saham. Secara pasrsial net proft margin berpengaruh positif dan signifikan terhadap harga saham artinya setiap penambahan satu kali net proft margin maka akan meningkatkan harga saham. Secara simultan current ratio dan net proft margin berpengaruh positif dan signifikan terhadap harga saham artinya jika current ratio dan net proft margin mengalami peningkatan maka akan meningkatkan harga saham.

\section{DAFTAR PUSTAKA}

Arifin, N. F., dan Agustami, S. (2016), "Pengaruh Likuiditas, Solvabilitas, Profitabilitas, Rasio Pasar, dan Ukuran Perusahaan Terhadap Harga Saham (Studi Pada Perusahaan Subsektor Perkebunan Yang Terdaftar Di Bursa Efek Indonesia Tahun 2010-2014)”, Jurnal Riset Akuntansi dan Keuangan, Vol 4 No. 3.
Darmadji \& Fakhrudin, H. (2012), "Pasar Modal di Indonesia”, Edisi Ketiga, Jakarta: Salemba Empat.

Fahmi, I. (2015). "Pengantar Manajemen Keuangan Teori dan Soal Jawab". Bandung: Alfabeta.

Ghozali, I. (2016). "Aplikasi Analisis Multivariete Dengan Program IBM SPSS 23 (Edisi 8)". Cetakan ke VIII. Semarang: Badan Penerbit Universitas Diponegoro.

Husein, U. (2013). Metode Penelitian untuk Skripsi dan Tesis. Jakarta: Rajawali.

Kadir, A., \& Phang, S. B. (2012). “Analisis Faktor-Faktor yang Mempengaruhi Net Profit Margin Perusahaan Manufaktur yang Terdaftar Pada Bursa Efek Indonesia”. Jurnal Manajemen dan Akuntansi Vol. 13 No.1.

Kasmir, (2016), "Analisis Laporan Keuangan”. Jakarta: PT Raja Grafindo.

Manoppo, V. C. O., dkk. (2017), "Pengaruh Current Ratio, Der, Roa Dan Npm Terhadap Harga Saham Pada Perusahaan Food and Beverages Yang Terdaftar Di BEI (Periode 20132015)", Jurnal EMBAVol.5 No.2.

Murhadi, W. R. (2013). "Analisis Laporan Keuangan, Proyeksi dan Valuasi Saham”. Jakarta: Salemba Empat.

Sartono, A. (2010). "Manajemen Keuangan Teori dan Aplikasi (4Th ed)".Yogyakarta: BPFE.

Solihin, D. (2019), "Pengaruh Current Ratio dan Debt to Equity Ratio Terhadap 
Return on Asset Pada PT Kalbe Farma”, Kreatif Jurnal Ilmiah Prodi

Manajemen Universitas Pamulang,

Vol. 7, No. 1.

Sugiyono. (2017), "Metode Penelitian

Kuantitatif, Kualitatif, dan R\&D”.

Bandung: Alfabeta, CV.

Syamsuddin, L. (2014). "Manajemen

Keuangan Perusahaan "Konsep

Aplikasi Dalam Perencanaan,

Pengawasan, dan Pengambilan

Keputusan”. Jakarta: Rajawali Press.

Yuliana, Indah. (2010). "Investasi Produk Keuangan Syariah”. Malang: UIN MALIKI Press. 